\title{
Ecological and Epidemiological Aspects of the Sand Fly (Diptera, Psychodidae) Fauna of the National Monument of Pontões Capixabas, State of Espírito Santo, Southeastern Brazil
}

Author(s): Adelson L. Ferreira, Aloisio Falqueto, Gabriel Grimaldi, Jr., Alexandre A. Peixoto, and Israel De S. Pinto

Source: Journal of Medical Entomology, 50(6):1215-1223.

Published By: Entomological Society of America

URL: http://www.bioone.org/doi/full/10.1603/ME13037

BioOne (www.bioone.org) is a nonprofit, online aggregation of core research in the biological, ecological, and environmental sciences. BioOne provides a sustainable online platform for over 170 journals and books published by nonprofit societies, associations, museums, institutions, and presses.

Your use of this PDF, the BioOne Web site, and all posted and associated content indicates your acceptance of BioOne's Terms of Use, available at www.bioone.org/page/terms of use.

Usage of BioOne content is strictly limited to personal, educational, and non-commercial use. Commercial inquiries or rights and permissions requests should be directed to the individual publisher as copyright holder. 


\title{
Ecological and Epidemiological Aspects of the Sand Fly (Diptera, Psychodidae) Fauna of the National Monument of Pontões Capixabas, State of Espírito Santo, Southeastern Brazil
}

\author{
ADELSON L. FERREIRA, ${ }^{1}$ ALOISIO FALQUETO, ${ }^{1}$ GABRIEL GRIMALDI, JR., ${ }^{2}$ \\ ALEXANDRE A. PEIXOTO, ${ }^{3,4}$ AND ISRAEL DE S. PINTO ${ }^{1,3,5}$
}

\begin{abstract}
J. Med. Entomol. 50(6): 1215-1223 (2013); DOI: http://dx.doi.org/10.1603/ME13037
ABSTRACT We evaluated the ecological and epidemiological aspects of the sand fly fauna in an area of the Atlantic Forest biome with records of visceral and cutaneous leishmaniasis. Sand fly collections at three different localities at the National Monument of Pontões Capixabas, State of Espírito Santo, Southeastern Brazil, were conducted by using two Centers of Disease Control and Prevention automatic light traps in the peridomiciliary environment and eight Centers of Disease Control and Prevention automatic light traps in the forested environment. Collections occurred during four consecutive nights within each of the months and locations: São Luiz (December 2009, May 2010, July 2010, and December 2010), Córrego Palmital de Baixo (September 2010 and October 2010), and Córrego São Bento (February 2011 and May 2011). We collected 21,138 sand flies belonging to 31 species and 14 genera. Of this total, 12,412 sand flies were captured in the peridomiciliary environment and 8,726 in the forested environment. All of the vector species, Lutzomyia longipalpis (=Lutzomyia longipalpis, sensu; Young and Duncan), Migonemyia migonei (=Lutzomyia migonei, sensu; Young and Duncan), and Nyssomyia intermedia (=Lutzomyia intermedia, sensu; Young and Duncan), occurred in significantly higher numbers in the peridomiciliary environment than compared with the forested environment. Our results highlight the importance of conservation in the forest remains of the National Monument of Pontões Capixabas, because of higher species richness and diversity. Furthermore, they indicate the epidemiological role of Lu. longipalpis as the vector of Leishmania infantum within the study area, and the no evident role of $\mathrm{Mg}$. migonei.
\end{abstract}

KEY WORDS Phlebotominae, Atlantic forest, Lutzomyia longipalpis

The Atlantic Forest is a major biodiversity hotspot, and one of the most fragmented and damaged forests in the world. Currently, the Atlantic Forest covers only $7 \%$ of its original area. Despite these disturbances, the Atlantic Forest remains extremely rich in biodiversity, sheltered in several conservations units along the Brazilian coast, with high endemism levels of tetrapods, avian species, insects, and other animals (Instituto de Pesquisas da Mata Atlântica [IPEMA] 2005, Mittermeier et al. 1998, Myers et al. 2000). The sympatric occurrence of animals acting as reservoirs and insects acting as vectors is a favorable scenario for the occurrence of vector-borne diseases such as yellow fever, malaria, and leishmaniasis.

${ }^{1}$ Departamento de Patologia, Universidade Federal do Espírito Santo, Ave. Marechal Campos 1468, 29043900 Vitória, Espírito Santo, Brazil.

${ }^{2}$ Laboratório de Patologia e Biointervenção, Centro de Pesquisa Gonçalo Moniz, Fiocruz, Rua Waldemar Falcão 121, 40296710 Salvador, Bahia, Brazil.

${ }^{3}$ Laboratório de Biologia Molecular de Insetos, Instituto Oswaldo Cruz, Ave. Brasil 4365, 21040360 Rio de Janeiro, Rio de Janeiro, Brazil.

${ }^{4}$ In memoriam.

${ }^{5}$ Corresponding author, e-mail: pintoisrael@gmail.com.
Human leishmaniasis is a spectral disease (ranging from self-limiting cutaneous infections to more serious progressive mucocutaneous and visceral forms) caused by protozoan parasites of the genus Leishmania (Ross, 1903). The ecological system in which a Leishmania species is maintained in nature is usually composed of a single or a small number of phlebotomine sand flies (which serve as arthropod vectors) and a few vertebrate wild or domestic animals of several different mammalian orders (that serve as reservoir hosts; Peters and Killick-Kendrick 1987). The parasite is transmitted from animals to sand flies, and then from the insects to humans.

Cutaneous leishmaniasis (CL) caused by Leishmania braziliensis (Vianna, 1911) occurs throughout the distribution of the species in the Atlantic Forest region of the Espírito Santo state. The parasite is usually transmitted by Nyssomyia intermedia (Lutz and Neiva, 1912; =Lutzomyia intermedia, sensu; Young and Duncan, 1994), but other sand fly species such as Nyssomyia neivai (Pinto 1926; =Lutzomyia neivai, sensu; Young and Duncan, 1994), Nyssomyia whitmani (Antunes and Coutinho, 1939; =Lutzomyia whitmani, sensu; Young and Duncan, 1994), and Migonemyia 
migonei (França, 1920; =Lutzomyia migonei, sensu; Young and Duncan, 1994) may be involved in some transmission cycles (Azevedo et al. 1990a,b; Ferreira et al. 2001; Lainson and Shaw 1998; Luz et al. 2000; Rangel and Lainson 2003; Pita-Pereira et al. 2005, 2009). Visceral leishmaniasis (VL) resulting from zoonotic transmission of Leishmania infantum (Nicolle, 1908 ) is also found in some northern areas of the Atlantic Forest biome of the State of Espírito Santo, and it seems to be transmitted by Lutzomyia longipalpis (Lutz and Neiva, 1912; =Lutzomyia longipalpis, sensu; Young and Duncan, 1994; Pinto et al. 2012a). The habit of keeping dogs and other domestic animals inside the house is thought to promote human infection, because dogs are peridomestic hosts of the parasite and attract phlebotomine sand flies, especially Lu. longipalpis. The population density of Lu. longipalpis can reach very high levels inside houses and in peridomestic settings (Deane 1956, Deane and Deane 1962, Lainson and Shaw 1998, Rangel and Lainson 2003). Molecular studies focusing on VL have shown that other sand fly species such as Mg. migonei (Carvalho et al. 2010) and Lutzomyia almerioi (Galati and Nunes, 1999; =Lutzomyia almerioi, sensu; Young and Duncan, 1994; Savani et al. 2009) can be naturally infected by the Leishmania parasite and can be acting as secondary vectors.

The predominant source of periodic fluctuations in the incidence of leishmaniasis is considered linked to the abundance of sand flies. To enable accurate timing of control measures, further studies on the dynamics of sand fly species vectors are required (World Health Organization [WHO] Expert Committee 2010). In the current study, we therefore evaluated the ecological and epidemiological aspects of the sand fly fauna of the National Monument of Pontões Capixabas (NMPC), State of Espírito Santo, Brazil. Our objectives were: 1) to assess the abundance and diversity of sand flies across the Atlantic Forest biome, 2) to investigate the population dynamics of potential vectors in peridomiciliary and forested environments within the NMPC, and 3) to identify the putative vectors of leishmaniasis within the study area.

\section{Materials and Methods}

Study Area. In Brazil, the "National Monument" category is applied to conservation units where the human population can live inside the geographical boundaries without expropriation of the land. Currently, $\approx 400$ families live inside the boundaries of the NMPC. The NMPC is situated in the central region of the Atlantic Forest, above the Doce River, and covers an area of $\approx 174.96 \mathrm{~km}^{2}$, including several Atlantic Forest remains and, predominantly, areas of farming and livestock. The NMPC is divided into two distinct areas: one belonging to the municipality of Pancas, and the other to the municipality of Águia Branca. Both of these areas are situated in the northwestern portion of the State of Espírito Santo, southeastern Brazil. The Brazilian name "Pontões" refers to the rocky outcrops that are very common along the NMPC, and are the main characteristic of the region's landscape. The Köppen-Geiger climate classification defines the NMPC as tropical monsoon (Peel et al. 2007), with low elevations $(<500 \mathrm{~m}$ [a.s.l.]), low annual rainfall $(<1,000 \mathrm{~mm}$; with the wet season from November to April and the dry season from May to October), and no marine influence (Feitoza 1986, Secretaria de Estado de Meio Ambiente e Recursos Hídricos [SEAMA] 2008).

The portion of the NMPC belonging to the municipality of Pancas is an endemic area of VL and CL. Based on the occurrence of leishmaniasis, we conducted sand fly captures in three selected localities (Fig. 1). The first locality, Córrego São Luiz $\left(19^{\circ} 10^{\prime} 25^{\prime \prime}\right.$ $\left.\mathrm{S} ; 40^{\circ} 51^{\prime} 08^{\prime \prime} \mathrm{W}\right)$, has recent records of VL and ancient records of CL. The second locality, Córrego Palmital de Baixo ( $19^{\circ} 12^{\prime} 47^{\prime \prime} \mathrm{S} ; 40^{\circ} 47^{\prime} 20^{\prime \prime} \mathrm{W}$ ), has records of $\mathrm{VL}$ $10 \mathrm{yr}$ ago (2003), but no recent records of $\mathrm{VL}$, and no records of CL. The third locality, Córrego São Bento $\left(19^{\circ} 13^{\prime} 44^{\prime \prime} \mathrm{S} ; 40^{\circ} 45^{\prime} 31^{\prime \prime} \mathrm{W}\right)$, has ancient records of CL, but no records of VL.

Sand Fly Collection Methods. In each locality, we conducted at least two sand fly captures as follows: São Luiz (December 2009, May 2010, July 2010, and December 2010), Córrego Palmital de Baixo (September 2010 and October 2010), and Córrego São Bento (February 2011 and May 2011). We used two Centers of Disease Control and Prevention automatic light traps in the peridomiciliary environment and eight Centers of Disease Control and Prevention automatic light traps in the forested environment, during four consecutive nights within each of the months listed earlier. Ten light traps were used for each night. In the peridomiciliary environment, the traps were placed close to domestic animal shelters. In the forest environment, the traps were placed randomly, at a distance of $30 \mathrm{~m}$ from each other and at least $50 \mathrm{~m}$ from the forest edge. The traps remained in operation throughout the night (1800-0600 hours). In total, 768 collection hours were amassed in the peridomestic environment, and 3,072 collections hours in the forest environment. A small container $(220 \mathrm{ml})$ with $80 \%$ ethanol was connected to the trap to store insects after the capture, instead of the meshed cages provided by the manufacturer. At the end of each night, we removed the containers, filled them with $80 \%$ ethanol, and transported them to the Laboratory of Parasitology, Universidade Federal do Espírito Santo. The sand flies were screened and mounted on glass slides, according to the technique proposed by Barreto and Coutinho (1940). We identified sand flies based on morphological characters (Galati 2003a), following the phylogenetic classification of Galati $(1995,2003 \mathrm{~b})$ and the generic name abbreviations of Marcondes (2007). Because the phylogenetic classification of Galati $(1995,2003 b)$ still remains controversial outside of Brazil, we used the classification of Young and Duncan (1994) in parentheses after the species' name and author. Sand fly vouchers were deposited in the Phlebotomine Collection of the Centro de Pesquisas René Rachou, FIOCRUZ, municipality of Belo Horizonte, State of Minas Gerais. 


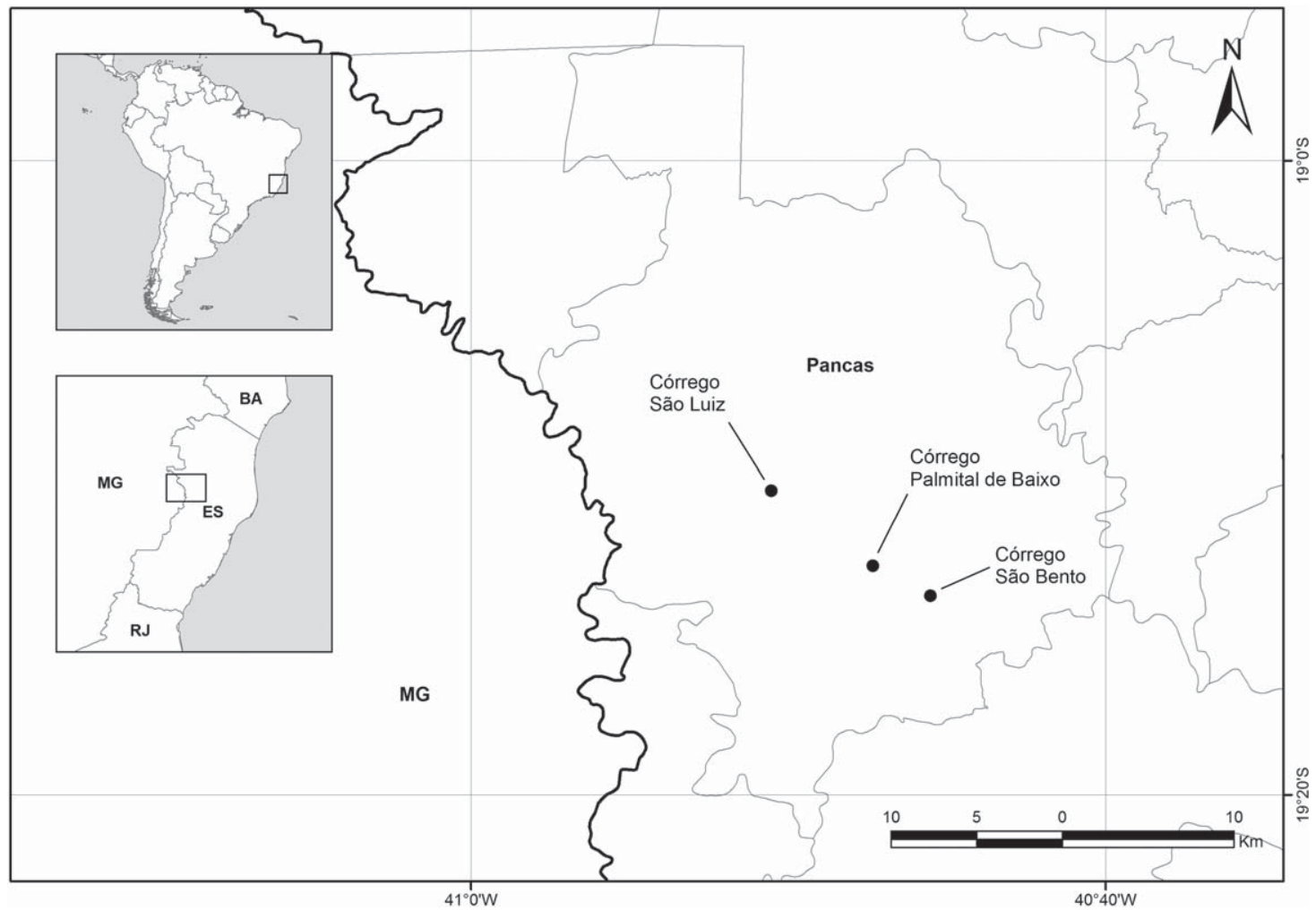

Fig. 1. Map showing collecting localities of sand flies at the National Monument of Pontões Capixabas, municipality of Pancas, State of Espírito Santo, southeastern of Brazil.

Statistical Analyses. We used the program PAST (Hammer et al. 2001) to calculate the species richness $(\mathrm{S})$, and the equitability $(\mathrm{J})$ and Shannon diversity $(\mathrm{H})$ indices.

\section{Results}

We collected 21,138 sand flies belonging to 31 species and 14 genera $(\mathrm{J}=0.54, \mathrm{H}=1.86)$. Of this total, 12,412 sand flies were captured in the peridomiciliary environment $(\mathrm{S}=19, \mathrm{~J}=0.48, \mathrm{H}=1.42$ ) and 8,726 in the forested environment $(\mathrm{S}=30, \mathrm{~J}=0.59, \mathrm{H}=2.03$ ). We excluded sand flies belonging to Brumptomyia spp. (=Brumptomyia spp., sensu; Young and Duncan, 1994), Evandromyia spp. (=Lutzomyia spp., sensu; Young and Duncan, 1994), and Pressatia spp. (=Lutzomyia (Pressatia) spp., sensu; Young and Duncan, 1994) from our analysis of equitability and diversity. In decreasing order, the three most captured species were Mg. migonei, Pressatia choti (Floch and Abonnenc, 1941; =Lutzomyia choti, sensu; Young and Duncan, 1994), and Lu. longipalpis in the peridomiciliary environment, and Pr. choti, Micropygomyia ferreirana (Barretto, Martins and Pellegrino, 1956; = Lutzomyia ferreirana, sensu; Young and Duncan, 1994), and $M g$. migone i in the forested environment. We collected no specimens of Lu. longipalpis in the locality of Córrego Palmital de Baixo, and only a single specimen in the locality of Córrego São Bento (captured in the for- ested environment). The species $\mathrm{Mg}$. migonei and $\mathrm{Ny}$. intermedia were collected in both kinds of environment, and in all three localities. The sand fly species Evandromyia termitophila (Martins, Falcão and Silva, 1964; =Lutzomyia termitophila, sensu; Young and Duncan, 1994) was captured only in the peridomiciliary environment. Brumptomyia avellari (Costa Lima, 1942; =Brumptomyia avellari, sensu; Young and Duncan, 1994), Brumptomyia figueiredoi (Mangabeira and Sherlock, 1961; =Brumptomyia figueiredoi, sensu; Young and Duncan, 1994), Evandromyia sallesi (Galvão and Coutinho, 1939; =Lutzomyia sallesi, sensu; Young and Duncan, 1994), Evandromyia sericea (Floch and Abonnenc, 1944; =Lutzomyia sericea, sensu; Young and Duncan, 1994), Martinsmyia gasparviannai (Martins, Godoy and Silva, 1962; =Lutzomyia gasparviannai, sensu; Young and Duncan, 1994), Micropygomyia capixaba (Dias, Falcão, Silva and Martins, 1987; =Lutzomyia capixaba, sensu; Young and Duncan, 1994), Pintomyia mamedei (Oliveira, Afonso, Dias and Brazil, 1994; =Lutzomyia mamedei, sensu; Young and Duncan, 1994), Psathyromyia lutziana (Costa Lima, 1932; =Lutzomyia lutziana, sensu; Young and Duncan, 1994), Psathyromyia pascalei (Coutinho and Barretto, 1940; =Lutzomyia pascalei, sensu; Young and Duncan, 1994), Psychodopygus hirsutus (Mangabeira, 1942; =Lutzomyia hirsuta, sensu; Young and Duncan, 1994), Sciopemyia microps (Mangabeira, 1942; = Lutzomyia microps, sensu; Young 
and Duncan, 1994), and Trichopygomyia longispina (Mangabeira, 1942; =Lutzomyia longispina, sensu; Young and Duncan, 1994) were captured only in the forested environment. We recorded the presence of Pi. mamedei in the State of Espírito Santo for the first time.

Tables 1 and 2 show the numbers of sand fly specimens, according to species and sex, captured during each collection month and in each one of the three localities, from the peridomiciliary environment and the forested environment. The tables also show the sex ratio, species richness, and equitability and Shannon diversity indices for each collection month. The ratio of males to females was at least two times higher in the peridomiciliary environment than in the forested environment. The success rates of capture were 16.16 sand flies per hour per trap from the peridomiciliary environment and 2.84 sand flies per hour per trap from the forested environment.

\section{Discussion}

In the current study, the species richness recorded in the peridomiciliary environment (i.e., the least conserved area) of the NMPC was in accordance with those of previous observations in the peridomiciliary environment of the Atlantic Forest, State of Espírito Santo (Pinto et al. 2010a, 2012a; Virgens et al. 2008). However, when we included in our analyses, specimens captured in the forested environment (i.e., the most conserved area) of the NMPC, the species richness increased significantly. In this regard, our results are in agreement with those of Bock et al. (2007), who demonstrated that correlations between species richness, evenness, and abundance for certain animals and plants supported the validity of species richness as an indicator of overall conservation value of an area (i.e., places with particular conservation value should include those with high species richness, but also those where desirable, e.g., generally rare or threatened, species or groups of species are especially abundant).

The high value of species richness found in the NMPC is also in accordance with those of previous studies that have identified the Central Corridor Region of the Atlantic Forest as a major biodiversity hotspot of the world (Orme et al. 2005). Carnaval et al. (2009) further recognized the Central Corridor Region as a hotspot within the Atlantic Forest hotspot, and a refuge for biodiversity during the climatic extremes of the Late Pleistocene. Based on species richness alone, our data also suggest the Central Corridor Region as a biodiversity hotspot within the Atlantic Forest, because the overall species richness of the NMPC was considerably higher than that of the south region (São Paulo refugium; Galati et al. 2010a,b; Marcondes et al. 2001), and that of the north region (Pernambuco refugium; Andrade et al. 2005, Cortez et al. 2007, Guimarães et al. 2012), of the Atlantic Forest. Considering only the Atlantic Forest within the State of Espírito Santo, the species richness was also the highest recorded (Pinto et al. 2010b, 2012b). It is possible that the high sand fly species richness in the central region of the Atlantic Forest is associated with the high diversity of vertebrates in the area (Costa et al. 2000, Myers et al. 2000, Pinto et al. 2009, Tonini et al. 2010), because many sand fly species show some species-specific preference for the host that provides them with a bloodmeal (Falqueto 1995).

Many previous studies have used species richness as the sole measure of diversity (Harper and Hawksworth 1994, Ricklefs and Schluter 1993). However, other studies have indicated that diversity can change with ecological processes such as competition, predation, and succession. Each of these processes alters the diversity through changes in evenness, without any change in species richness (Stirling and Wilsey 2001, Wilsey and Potvin 2000). In the current study, we therefore also evaluated the Shannon diversity index, which provides diversity information that unites species richness and relative species abundance. In addition, we calculated the Shannon diversity index for previous studies that had not considered species diversity to conduct the comparisons between different areas. In contrast to species richness, we detected no relationship between a high Shannon diversity and hotspots within the Atlantic Forest biome, because of variations in evenness. Nevertheless, the presence of rare species (e.g., Ev. sericea, Pi. mamedei, and Mt. gasparviannai) highlights the conservation value of the NMPC, because rare species can be used as indicator groups for conservation planning (Lawler et al. 2003). We further revealed that, similar to species richness, sand fly diversity in forested environments is clearly higher than that in peridomiciliary areas, even within the same study area (Galati et al. 2010a,b; Pinto et al. $2012 \mathrm{a}, \mathrm{b})$.

Our present data therefore indirectly support the hypothesis that high species richness and diversity of sand flies may be associated with high genetic diversity of Leishmania parasites. Souza-Rocha et al. (2010) studied natural infection by Leishmania in sand fly species collected in the State of Espírito Santo and observed a relationship between high species richness of sand flies and high genetic diversity of Leishmania parasites. In addition, Cupollilo et al. (2003) studied the genetic diversity of Leishmania braziliensis from different regions of Brazil and observed that parasites isolated from the State of Espírito Santo belonged to two distinct groups: 1) isolates from urban areas clustered with isolates from the State of Rio de Janeiro (lower genetic diversity), and 2) isolates from rural areas clustered with isolates from the State of Pernambuco (higher genetic diversity). The first group is composed of parasites isolated from the municipality of Viana and neighboring municipalities, and the second group consists of parasites isolated from municipalities bordering the NMPC. Indirectly, our data support this hypothesis because the values of species richness and diversity of sand flies that we recorded from the NMPC (second group) were higher than the values recorded from Viana and neighboring municipalities (first group; Barros et al. 1985, Pinto et al. 2010b). 


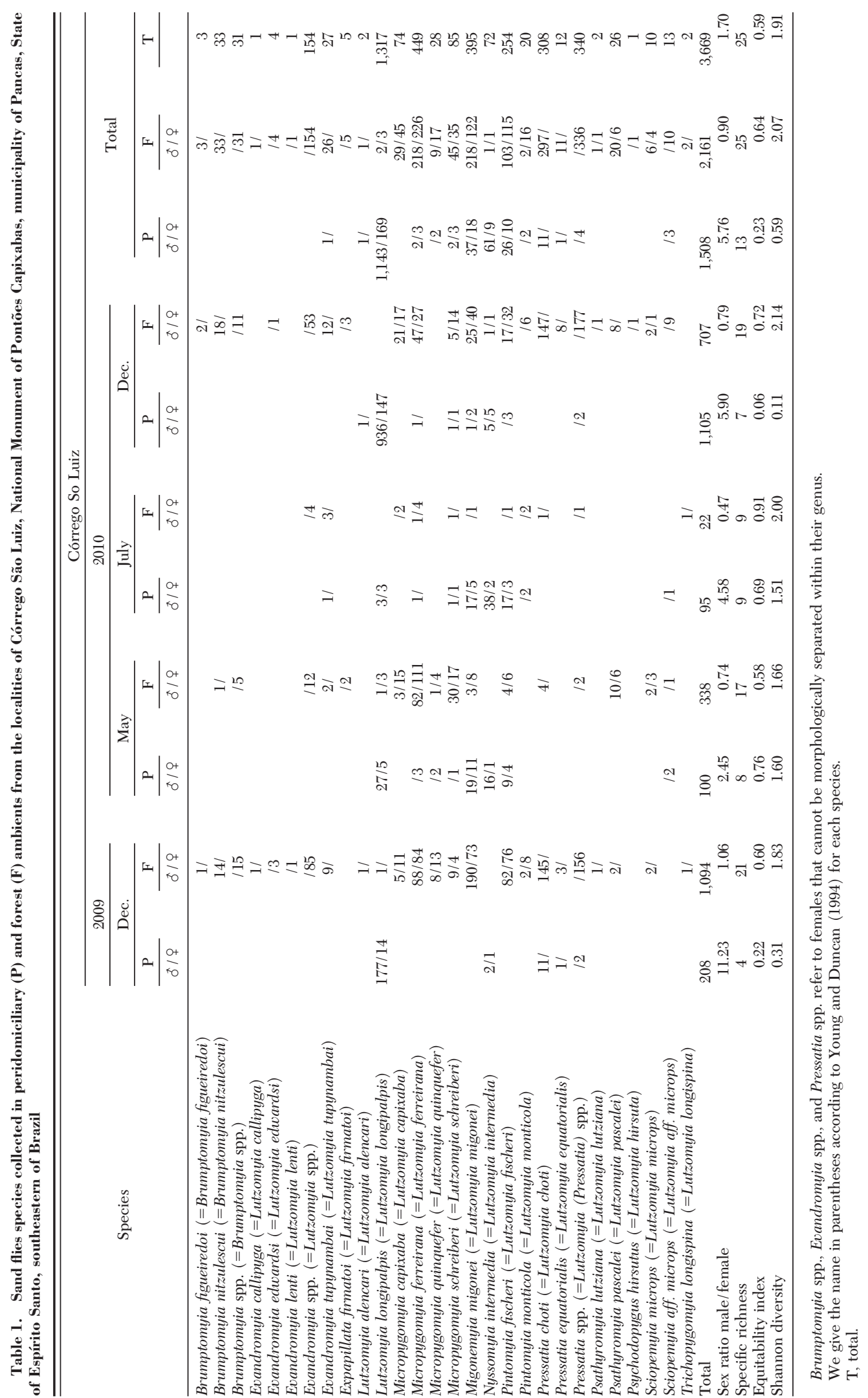




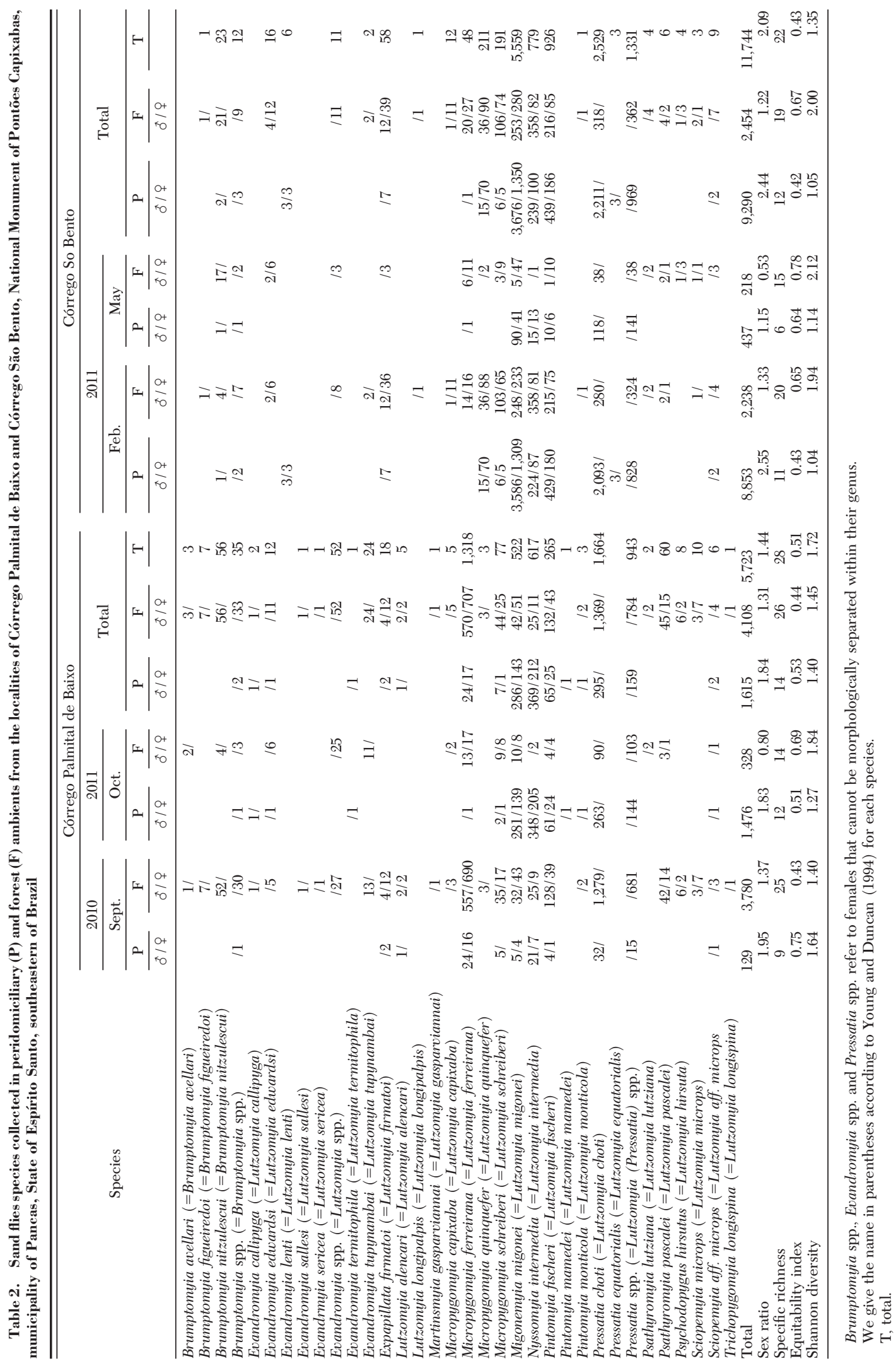


In the current study, we also evaluated the vector dynamics of leishmaniasis-endemic areas in the Atlantic Forest, which is relevant to the epidemiology of leishmaniasis. We revealed that the human population in the endemic area of NMPN is exposed to risk of infection by Leishmania throughout the year, because Lu. longipalpis was always captured in the peridomiciliary environment. Furthermore, we propose that infection occurs in the peridomiciliary environment, because sand flies vectors of all species were more abundant in this environment. Pinto et al. (2012a) also demonstrated a high abundance of sand fly vectors in the peridomiciliary environment of endemic areas of American VL, across the Central Atlantic Forest Biodiversity Corridor. Epidemiological surveys of human and canine visceral infections caused by L. infantum in rural areas of the municipality of Pancas have revealed similar findings (Falqueto et al. 2009). These surveys showed no significant differences in $L$. infantum infection rates within the human population according to gender or age, indicating that transmission occurs in the home and in the peridomestic setting. The occurrence of human infections caused by Leishmania in the peridomiciliary environment of the Atlantic Forest (Rangel 1995, Tolezano 1994) contrasts with the Amazon region, where almost all human infections caused by Leishmania are associated with wild environments (Guerra et al. 2011, Martins et al. 2004).

Based on the results of our current study, we believe that $L u$. longipalpis is the main vector of $L$. infantum in the NMPC, and that Mg. migonei plays an no evident role. These assertions are supported by the absence of Lu. longipalpis, and the presence of Mg. migonei, in the peridomiciliary environments of areas with no recent records of $L$. infantum (Córrego Palmital de Baixo), and in areas where L. infantum has never been recorded (Córrego São Bento). By contrast, Mg. migonei acts as vector of $L$. infantum in an area of the State of Pernambuco, in the northern portion of the Atlantic Forest (Carvalho et al. 2010), and appears to act as vector in the City of La Banda, Argentina (Salomón et al. 2010).

In conclusion, we have demonstrated that species richness and diversity of sand flies is congruent with biodiversity hotspots of the Atlantic Forest. Furthermore, species richness and diversity of sand flies might be associated to the genetic diversity of the Leishmania parasite. Epidemiologically, we have reinforced the relationship between peridomiciliary and domiciliary environments, and the transmission pattern of Leishmania parasites in the Atlantic Forest. Finally, our data indicate $L u$. longipalpis as the vector of $L$ infantum within our study area.

\section{Acknowledgments}

We thank Antonio Teva, Daniel Kiefer, Felipe Vigoder, and Luiz G. S. R. Bauzer for the help in the fieldwork. We also thank Gustavo R. Leite for the preparation of the map. This work was supported by the Conselho Nacional de Desenvolvimento Científico e Tecnológico ( $\mathrm{CNPq}$, Brazil) and FIOCRUZ.

\section{References Cited}

Andrade, M. S., H. F. Valença, A. L. Silva, F. A. Almeida, E. L. Almeida, M.E.F. Brito, and S. P. Brandão-Filho. 2005. Sand fly fauna in a military training area endemic for American tegumentary leishmaniasis in the Atlantic Rain Forest region of Pernambuco, Brazil. Cadernos de Saúde Pública 21: 1761-1767.

Azevedo, A.C.R., E. F. Rangel, E. M. Costa, J. David, A. W. Vasconcelos, and U. G. Lopes. 1990a. Natural infection of Lutzomyia (Nyssomyia) whitmani (Antunes \& Coutinho, 1939) by Leishmania of the braziliensis complex in Baturité, Ceará state, northeast Brazil. Memorias do Instituto Oswaldo Cruz 85: 251.

Azevedo, A.C.R., E. F. Rangel, and R. G. Queiroz. 1990b. Lutzomyia migonei (França, 1920) naturally infected with peripylarian flagellates in Baturité, a focus of cutaneous leishmaniasis in Ceará state, Brazil. Memorias do Instituto Oswaldo Cruz 85: 479.

Barreto, M. P., and J. O. Coutinho. 1940. Processos de captura, dissecação e montagem de flebótomos. Anais da Faculdade de Medicina da Universidade de São Paulo 16: 173-187.

Barros, G. C., P. A. Sessa, E. A. Mattos, V.R.D. Carias, W. Mayrink, J.T.A. Alencar, A. Falqueto, and A. C. Jesus. 1985. Foco de leishmaniose tegumentar nos municípios de Viana e Cariacica, estado do Espírito Santo, Brasil. Revista de Saúde Pública 19: 146-153.

Bock, C. E., Z. F. Jones, and J. H. Bock. 2007. Relationships between species richness, evenness, and abundance in a south-western savanna. Ecology 88: 1322-1327.

Carnaval, A. C., M. J. Hickerson, C.F.B. Haddad, M. T. Rodrigues, and C. Moritz. 2009. Stability predicts genetic diversity in the Brazilian Atlantic Forest Hotspot. Science 323: 785-789.

Carvalho, M. R., H. F. Valença, F. J. Silva, D. Pita-Pereira, T. A. Pereira, C. Britto, R. P. Brazil, and S. P. BrandãoFilho. 2010. Natural Leishmania infantum infection in Migonemyia migonei (França, 1920) (Diptera: Psychodidae: Phlebotominae) the putative vector of visceral leishmaniasis in Pernambuco State, Brazil. Acta Trop. 116: $108-110$.

Cortez, A. M., V.P.M. Silva, P.V.S. Queiroz, H.T.A. Andrade, M.I.B. Loiola, and M.F.F.M. Ximenes. 2007. Vertical stratification and development aspects of phlebotomine sand flies (Diptera: Psychodidae) in an area of Atlantic Forest tree species in a metropolitan region in northeastern Brazil. J. Vector Ecol. 32: 336-341.

Costa, L. P., Y.L.R. Leite, G.A.B. Fonseca, and M. T. Fonseca. 2000. Biogeography of South American forest mammals: endemism and diversity in the Atlantic Forest. Biotropica 32: 872-881.

Cupollilo, E., L. R. Brahim, C. B. Toaldo, M. P. OliveiraNeto, M.E.F. Brito, A. Falqueto, M. F. Naiff, and G. Grimaldi, Jr. 2003. Genetic polymorphism and molecular epidemiology of Leishmania (Viannia) braziliensis from different hosts and geographic areas in Brazil. J. Clin. Microbiol. 41: 3126-3132.

Deane, L. M. 1956. Leishmaniose visceral no Brasil. Estudos sobre reservatórios e transmissores no estado do ceará. Serviço Nacional de Educação Sanitária, Rio de Janeiro, Brazil.

Deane, L. M., and M. P. Deane. 1962. Visceral leishmaniasis in Brazil: Geographical distribution and transmission. Revista do Instituto de Medicina Tropical de Sao Paulo 4: 198-212.

Falqueto, A. 1995. Especificidade alimentar de flebotomíneos em duas áreas endêmicas de leishmaniose tegumentar no 
Estado do Espírito Santo. Doctoral thesis, Instituto Oswaldo Cruz, Fundação Oswaldo Cruz, Rio de Janeiro, Brazil.

Falqueto, A., A. L. Ferreira, C. B. Santos, R. Porrozzi, M. V. Costa, A. Teva, E. Cupolillo, A. Campos-Neto, and G. Grimaldi, Jr. 2009. Crosssectional and longitudinal epidemiologic surveys of human and canine Leishmania infantum visceral infections in an endemic rural area of southeast Brazil (Pancas, Espírito Santo). Am. J. Trop. Med. Hyg. 80: 559-565.

Feitoza, L. R. 1986. Carta agroclimática do Espírito Santo. Governo do estado do Espírito Santo. Secretaria de Estado da Agricultura and Empresa Capixaba de Pesquisa Agropecuária EMCAPA Vitória, ES, Brazil.

Ferreira, A. L., P. A. Sessa, J.B.M. Varejão, and A. Falqueto. 2001. Distribution of sand flies (Diptera: Psychodidae) at different altitudes in an endemic region of American cutaneous leishmaniasis in the state of Espírito Santo, Brazil. Memorias do Instituto Oswaldo Cruz 96: 10611067.

Galati, E.A.B. 1995. Phylogenetic systematics of Phlebotominae (Diptera, Psychodidae) with emphasis on American groups. Boletín de la Dirección de Malariología Y Saneamiento Ambiental 35: 133142.

Galati, E.A.B. 2003a. Morfologia e Taxonomia. 2.1: classificação de Phlebotominae, pp. 23-51. In E. F. Rangel and R. Lainson (eds.), Flebotomíneos do Brasil. Editora Fiocruz, Rio de Janeiro, Brazil.

Galati, E.A.B. 2003b. Morfologia e Taxonomia. 2.2: morfologia, terminologia de adultos e identificação dos táxons da América, pp. 53-175. In E. F. Rangel and R. Lainson (eds.), Flebotomíneos do Brasil. Editora Fiocruz, Rio de Janeiro, Brazil.

Galati, E.A.B., A. M. Marassá, R. M. Gonçalves-Andrade, C. A. Consales, and E.M.F. Bueno. 2010a. Phlebotomines (Diptera, Psychodidae) in the Ribeira Valley Speleological Province 1. Parque Estadual Intervales, state of São Paulo, Brazil. Revista Brasileira de Entomologia 54: 311321

Galati, E.A.B., A. M. Marassá, R. M. GonçalvesAndrade, C. A. Consales, and E.F.M. Bueno. 2010b. Phlebotomines (Diptera, Psychodidae) in the Speleological Province of the Ribeira Valley: 2. Parque Estadual do Alto Ribeira (PETAR), São Paulo State, Brazil. Revista Brasileira de Entomologia 54: 477-487.

Guerra, J.A.O., M.G.V. Barbosa, M. G. Paes, R. T. Sousa, P. G. Silva, M. J. Silva, A. R. Macião, R. S. Carvalho, L.I.A.R.C. Coelho, and L.C.L. Ferreira. 2011. Mucosal leishmaniasis-clinical and epidemiological aspects of 234 cases treated in a tertiary reference center in the Brazilian Amazon. J. Community Med. Health Edu. 1: 1-4.

Guimarães, V.C.F.V., P. L. Costa, F. J. Silva, K. T. Silva, K. G. Silva, A.I.F. Araújo, E.H.G. Rodrigues, and S. P. BrandãoFilho. 2012. Phlebotomine sandflies (Diptera: Psychodidae) in São Vicente Férrer, a sympatric area to cutaneous and visceral leishmaniasis in the state of Pernambuco, Brazil. Revista da Sociedade Brasileira de Medicina Tropical 45: 66-70.

Harper, J. L., and D. L. Hawksworth. 1994. Biodiversity: measurement and estimation. Philos. Trans. R. Soc. Lond. B Biol. Sci. 345: 5-12.

Hammer, Ø., D.A.T. Harper, and P. D. Ryan. 2001. PAST: palaeontological Statistics software package for education and data analysis. Palaent. Electron 4: 1-9.

(IPEMA) Instituto de Pesquisas da Mata Atlântica. 2005. Conservação da Mata Atlântica no estado do Espírito Santo: cobertura florestal, unidades de conservação e fauna ameaçada. Programa Centros para a Conservação da Biodiversidade/Conservação Internacional do Brasil/
Instituto de Pesquisas da Mata Atlântica, Vitória, Espírito Santo, Brazil.

Lainson, R., and J. J. Shaw. 1998. New World leishmaniasis the neotropical leishmania species, pp. 241-266. In L. Collier, A. Baeows, and M. Sussman (eds.), Topley \& Wilson's Microbiology and Microbial Infections, Parasitology. Arnold, London, United Kingdom.

Lawler, J. J., D. White, J. C. Sifneos, and L. L. Master. 2003. Rare species and the use of indicator groups for conservation planning. Conserv. Biol. 17: 875-882.

Luz, E., N. Membrive, E. A. Castro, J. Dereure, J. Pratlong, A. Dedet, A. Pandey, and V. Thomaz-Soccol. 2000. Lutzomyia whitmani (Diptera: Psychodidae) as vector of Leishmania (V). braziliensis in Paraná State, southern Brazil. Ann. Trop. Med. Parasitol. 94: 623-631.

Marcondes, C. B. 2007. A proposal of generic and subgeneric abbreviations for Phlebotomine sandflies (Diptera: Psychodidae: Phlebotominae) of the world. Entomol. News. 118: 351-356.

Marcondes, C. B., L. G. Santos-Neto, and A. L. Lozovei. 2001. Ecology of Phlebotomine sandflies (Diptera, Psychodidae) in Brazilian Atlantic Forest. Rev. Soc. Bras. Med. Trop. 34: 255-260.

Martins, L. M., J.M.M. Rebêlo, M.C.F.V. Santos, J.M.L. Costa, A. R. Silva, and L. A. Ferreira. 2004. Ecoepidemiologia da leishmaniose tegumentar no Município de Buriticupu, Amazônia do Maranhão, Brasil, 1996 a 1998. Cadernos de Saúde Pública 20: 735-743.

Mittermeier, R. A., N. Myers, J. B. Thomsen, G. A. B da Fonseca, and S. Olivieri. 1998. Biodiversity hotspots and major tropical wilderness areas: approaches to setting conservation priorities. Conserv. Biol. 12: 516520.

Myers, N., R. A. Mittermeier, C. G. Mittermeier, G.A.B. Fonseca, and J. Kent. 2000. Biodiversity hotspots for conservation priorities. Nature 403: 853-858.

Orme, C.D.L., R. G. Davies, M. Burgess, F. Eigenbrod, N. Pickup, V. A. Olson, A. J. Webster, T. S. Ding, P. C. Rasmussen, R. S. Ridgely, A. J. Stattersfield, P. M. Bennett, T. M. Blackburn, K. J. Gaston, and I.P.F. Owens. 2005. Global hotspots of species richness are not congruent with endemism or threat. Nature 436: 1016-1019.

Peel, M. C., B. L. Finlayson, and T. A. McMahon. 2007. Updated world map of the Köppen-Geiger climate classification. Hydrol. Earth Syst. Sci. 11: 1633-1644.

Peters, W., and R. Killick-Kendrick. 1987. The leishmaniases in biology and medicine: biology and epidemiology, vol. 1. Academic, Oxford, United Kingdom.

Pinto, I. S., A.C.C. Loss, A. Falqueto, and Y.L.R. Leite. 2009. Pequenos mamíferos não voadores em fragmentos de Mata Atlântica e áreas agrícolas em Viana, Espírito Santo, Brasil. Biota Neotropica 9: 355-360.

Pinto, I. S., C. B. Santos, A. L. Ferreira, and A. Falqueto. 2010a. American visceral leishmaniasis dissociated from Lutzomyia longipalpis (Diptera, Psychodidae) in the state of Espírito Santo, Brazil. Cadernos de Saúde Pública 26: 365-372.

Pinto, I. S., C. B. Santos, A. L. Ferreira, and A. Falqueto. 2010b. Richness and diversity of sand flies (Diptera, Psychodidae) in an Atlantic rainforest reserve in southeastern Brazil. J. Vector Ecol. 35: 325-332.

Pinto, I. S., A. L. Ferreira, V. Valim, F. S. Carvalho, G. M. Silva, A. L. Falcão, R. Dietze, and A. Falqueto. 2012a. Sand fly vectors (Diptera, Psychodidae) of American visceral leishmaniasis areas in the Atlantic Forest, State of Espírito Santo, Brazil. J. Vector Ecol. 37: 90-96.

Pinto, I. S., J.F.R. Tonini, A. L. Ferreira, and A. Falqueto. 2012b. A brief inventory of sand flies (Diptera, Psychodidae) from the National Forest of the Rio Preto, state of 
the Espírito Santo, southeastern Brazil. Biota Neotropica 12: 323-326.

Pita-Pereira, D., C. R. Alves, M. B. Souza, R. P. Brazil, A. L. Bertho, A. Figueiredo-Barbosa, and C. Britto. 2005. Identification of naturally infected Lutzomyia intermedia and Lutzomyia migonei with Leishmania (Viannia) braziliensis in Rio de Janeiro (Brazil) revealed by a PCR multiplex non-isotopic hybridization assay. Trans. R. Soc. Trop. Med. Hyg. 99: 905-913.

Pita-Pereira, D., G. D. Souza, A. Zwetsch, C. R. Alves, C. Britto, and E. F. Rangel. 2009. First report of Lutzomyia (Nyssomyia) neivai (Diptera: Psychodidae: Phlebotominae) naturally infected by Leishmania (Viannia) braziliensis in a periurban area of south Brazil using a multiplex polymerase chain reaction assay. Am. J. Trop. Med. Hyg. 80: 593-595.

Rangel, E. F. 1995. Transmission of American cutaneous leishmaniasis in peridomestic foci in Rio de Janeiro State and other similar situations compared to the classical epidemiology in Amazon region, vol. 2, pp. 103-110. In Proceedings from a Research Seminar on Tropical Diseases, Society and the Environment. Special Programme for Research and Training in Tropical Diseases/SAREC, Geneva, Switzerland.

Rangel, E. F., and R. Lainson. 2003. Flebotomíneos do Brasil. Editora Fiocruz, Rio de Janeiro, Brazil.

Ricklefs, R. E., and D. Schluter. 1993. Species diversity in ecological communities: historical and geographical perspectives. University of Chicago Press, Chicago, IL.

Salomón, O. D., M. G. Quintana, G. Bezzi, M. L. Morán, E. Betbeder, and D. V. Valdéz. 2010. Lutzomyia migonei as putative vector of visceral leishmaniasis in La Banda, Argentina. Acta Trop. 113: 84-87.

Savani, E.S.M.M., V.L.B. Nunes, E.A.B. Galati, T. M. Castilho, R. A. Zampieri, and L. M. Floter-Winter. 2009. The finding of Lutzomyia almerioi and Lutzomyia longipalpis naturally infected by Leishmania spp. in a cutaneous and canine visceral leishmaniases focus in Serra da Bodoquena, Brazil. Vet. Parasitol. 160: 18-24.
(SEAMA) Secretaria de Estado de Meio Ambiente e Recursos Hídricos. 2008. Atlas de Ecossistemas do Estado do Espírito Santo. UFV, Vitória, Espírito Santo, Brazil.

Souza-Rocha, L., A. Falqueto, C. B. Santos, A. L. Ferreira, G. C. Graça, G. Grimaldi, Jr., and E. Cupolillo. 2010. Survey of natural infection by Leishmania in sand fly species collected in southeastern Brazil. Trans. R. Soc. Trop. Med. Hyg. 104: 461-466.

Stirling, G., and B. Wilsey. 2001. Empirical relationships between species richness, evenness, and proportional diversity. Am. Nat. 158: 286-299.

Tolezano, J. E. 1994. Ecoepidemiological aspects of American cutaneous leishmaniasis in the State of São Paulo, Brazil. Memorias do Instituto Oswaldo Cruz 89: 427-434.

Tonini, J.F.R., L. M. Carão, I. S. Pinto, J.L.R. Gasparini, Y.L.R. Leite, and L. P. Costa. 2010. Non-volant tetrapods from Duas Bocas Biological Reserve, state of Espírito Santo, southeastern Brazil. Biota Neotrop. 10: 339-351.

Virgens, T. M., C. B. Santos, I. S. Pinto, K. S. Silva, F. C. Leal, and A. Falqueto. 2008. Phlebotomine sand flies (Diptera, Psychodidae) in an Am. tegumentary leishmaniasis transmission area in northern Espírito Santo state, Brazil. Cadernos de Saúde Pública 24: 2969-2978.

Wilsey, B. J., and C. Potvin. 2000. Biodiversity and ecosystem functioning: the importance of species evenness and identity in a Quebec old field. Ecology 81: 887-893.

(WHO) World Health Organization Expert Committee. 2010. Control of the leishmaniases. Technical Report Series 949. World Health Organization, Geneva, Switzerland.

Young, D. G., and M. A. Duncan. 1994. Guide to the identification and geographic distribution of Lutzomyia sand flies in Mexico, the West Indies, Central and South America (Diptera: Psychodidae). Memoirs of the American Entomological Institute, Associated Publishers-American Entomological Institute, Gainesville, FL.

Received 22 February 2013; accepted 23 August 2013. 